\title{
Refah Rejimleri Bağlamında Babalık Yönelimli Aile Politikaları
} Fatherhood-Oriented Family Policies in the Context of Welfare Regimes

Ahmet Elnur*

Öz: Günümüzde aile politikaları, toplumsal cinsiyet ideolojisinin yeniden üretildiği ve sürdürüldüğü temel alanlardan biri olarak öne çıkmaktadır. 20. yüzyılın son çeyreğinden itibaren, aile refahının geliştirilmesine yönelik sistematik çabaların artmasına paralel olarak babalık yönelimli aile politikaları gibi yeni uygulamaların gündeme gelmeye başladığı görülmektedir. Toplumsal cinsiyet ideolojisi çerçevesinde ortaya çıan ve şekillenen bu uygulamalarda, ülkeden ülkeye değişiklik gösteren önemli farklılıklar söz konusu olmaktadır. Aile politikalarının hem kadınlar hem de erkekler açısından geliştirilmesine yönelik Avrupa Birliği düzeyinde yasal ve politik tedbirler alınmasına rağmen; bu farklılıkların varlığını sürdürmeye devam ettiği görülmektedir. Genel olarak aileye, özel olarak babalığa yönelik desteklerin niteliğine göre farklılık gösteren aile politikası uygulamalarının açıklanmasında; Esping-Andersen'in 1990 yılında ortaya attığı üçlü refah devleti tipolojisi, üzerinden bunca zaman geçmesine rağmen önemli bir başvuru kaynağı olarak geçerliliğini korumaktadır. Bu çalışma kapsamında; refah rejimleri bağlamında babalık yönelimli aile politikalarının toplumsal cinsiyet ideolojisi etkisi altında nasıl şekillendiklerinin ortaya konulması amaciyla liberal, muhafazakâr ve sosyal demokrat refah rejimlerinde geçerli olan aile politikası uygulamaları karşılaştırmalı olarak incelenmektedir.

Anahtar Kelimeler: Aile Politikaları, Babalık, Toplumsal Cinsiyet, Refah Rejimi Sinıflandırmaları, Gøsta Esping-Andersen

\begin{abstract}
Recently, family policies are becoming prominent as one of the basic fields in which gender ideology is reproduced and sustained. Since the last quarter of the 20th century, in parallel with the increasing systematic efforts towards the development of family welfare, it has been seen that new practices such as fatherhoodoriented family policies are brought to agenda. Important differences that vary from country to country come into question in these practices that emerged and shaped as part of the gender ideology. Despite the fact that legal and political measures have been taken towards the development of family policies at European Union level for both women and men; it has been observed that these differences continue to exist. Three worlds of welfare typology suggested by Esping-Andersen in 1990, even after all this time, still stands as a valid reference guide in accordance with the explanation of family policies that differ by the characteristics of the support applied towards the family in general, and fatherhood in particular. Within the frame of the purpose of revealing how the fatherhood-oriented family policies are shaped under the influence of the gender ideology in the context of welfare governments; family policy practices which are prevalent in liberal, conservative and social democratic welfare governments are comparatively analyzed as part of this study.
\end{abstract}

\footnotetext{
* Öğr. Gör., Süleyman Demirel Üniversitesi, Rektörlük, ahmetelnur@sdu.edu.tr.
} 
Keywords: Family Policies, Fatherhood, Gender, The Classifications of Welfare Regimes, Gøsta EspingAndersen

\section{Giriş}

Küresel, toplumsal, kültürel ve ekonomik değişimlerin ailenin kurumsal yapısı üzerindeki etkileri her geçen gün artarak devam etmektedir. Bu etkileşim sürecinin bir sonucu olarak ailelerin; özellikle çocukların sağlıklı bir şekilde yetiştirilmesi, bakımı ve gelişimi gibi konularda çeşitli sorunlarla karşı karşıya kalması kaçınılmaz bir durum hâline gelmektedir. Söz konusu değişimler sadece küçük bir sosyal grup olarak kabul edilen ailenin değil, bir bütün olarak toplumun dönüşümüne neden olmaktadır. Yaşanan bu dönüşümler, aile ve evlilik konularına ilginin artmasına neden olmakta ve devletin konuya ilişsin daha bütünsel ve dinamik bir bakış açısı ile bakmasının gerekliliğini ortaya koymaktadır. Bu noktada, devletler tarafından çeşitli politikalar geliştirilerek aile kurumunun sürekliliğinin sağlanması doğrultusunda çabalar gösterildiği gözlenmektedir.

Aile ve evlilik konularına ilginin artması ile birlikte, aile politikaları üzerine farklı bakış açılarının ele alındığı çalışmaların yapılmaya başlandığı görülmektedir. Aile politikalarının toplumsal cinsiyet açısından incelendiği çalışmalarda, daha çok kadınların statüsü üzerine odaklanılmaktadır. Duncan'ın (2000: 12) ifade ettiği gibi devletin kadınları hem anne hem de işçi olarak ne derecede desteklediği, uygulanan politikaların söz konusu ülkedeki kadınlara yönelik duyarlılık düzeyinin belirlenmesindeki temel ölçüt olarak değerlendirilmektedir. Mevcut yaklaşımların toplumsal cinsiyete duyarlı olmamaları, feminist perspektiften yapılan çalışmaların temel eleştiri noktası olarak öne çıkmaktadır. Özellikle, Esping-Andersen'in üçlü refah devleti tipolojisinin kadının statüsü açısından çeşitli eleştirilere konu olduğu görülmektedir. "Three Worlds of Welfare Capitalism" çalışmasında yazarın refah rejimleri arasındaki farklılıkların belirlenmesi amacıyla kullandığı "dekomüdifikasyon” kavramının ele alınış biçimi, eleştirilerin temel çıkış noktasını oluşturmaktadır. Esping-Andersen (1990: 37), dekomüdifikasyonu "bireylerin veya ailelerin piyasa katılımından bağımsız olarak sosyal açıdan kabul edilebilir bir yaşam standardını gerçekleştirebilme düzeyleri” olarak tanımlamaktadır. Park (2002: 80) “toplumsal cinsiyet körü” olarak değerlendirdiği bu kavramı, kadınları göz ardı ettiğinden dolayı eleştirmektedir. Lewis de (1992: 161) Park’ın eleştirilerine katılmakta ve refah devleti sınıflandırmasında, doğum nedeniyle emek piyasasından çekildikleri gerekçesiyle kadınların anne, eş, işçi ve vatandaş olarak deneyimlerinin görmezden gelindiğini ifade etmektedir.

Feminist eleştirinin etkisiyle başlayan refah devletlerinin toplumsal cinsiyet bağlamında incelenmesi çalışmalarında özellikle annelik ve çocuk bakımı konularına odaklanılmıştır (Hobson, 
1994: 186). Erkeklerin işçi ve vatandaş olarak ana akım yaklaşımların merkezinde yer alması eleştirisinden yola çıkan feminist araştırmacılar; kadının konumunun altını çizmiş, erkekliği ve babalığı ise bir sorun olarak dikkate almamışlardır. Bir taraftan kadınlar emek piyasasında temsil edilmedikleri için görünmez hâle gelmiştir; öte yandan erkekler ise sadece bir toplumsal statü grubunun üyesi veya vatandaş olarak görülmüştür ancak aile içindeki konumları hesaba katılmamıştır. Bu çerçevede, refah devletlerinin aile politikalarının incelendiği çalışmalarda, bir toplumsal cinsiyet asimetrisinin oluştuğunu söylemek mümkündür (Hobson ve Morgan, 2002: 8). Söz konusu asimetrinin ortadan kaldırılması için yapılan çalışmalarda hem kadınların annelik hem de erkeklerin babalık deneyimlerinin dikkate alınması, aile politikaları kapsamında ebeveynlere (hem anne hem de babalara) verilen desteklere ve aile politikaları çerçevesinde, ebeveynlik modellerinin hangisinde ne gibi değişimler olduğuna odaklanılması önem taşımaktadır.

Çalışma kapsamında, Esping-Andersen'in üçlü refah devleti sınıflandırması bağlamında, aile politikalarında babalık yönelimli uygulamalar; ebeveynlik izni özelinde incelenmektedir. Söz konusu uygulamaların toplumsal cinsiyet ideolojisi etkisi altında nasıl şekillendiği araştırılmaktadır. Bu doğrultuda, öncelikle aile politikası kavramı ve aile politikalarında babalığın yeri ile ilgili genel bir çerçeve çizilmektedir. Daha sonra liberal, muhafazakâr ve sosyal demokrat refah rejimlerinde geçerli olan aile politikalarında babalık yönelimli uygulamalar karşılaştırmalı olarak incelenmektedir. Çalışmanın son bölümünde ise babalık yönelimli aile politikalarının uygulanmasındaki sorunlar tartışılmaktadır.

\section{Aile Politikası Kavramı}

Aile politikası kavramı, doğrudan veya dolaylı bir şekilde aile kurumunun desteklenmesi doğrultusunda devlet tarafından gerçekleștirilen uygulamaların bütününü tanımlamak için kullanılmaktadır. Daly'nin (2002: 14) de ifade ettiği gibi aile politikaları kavramı; genellikle devlet tarafından çocuklu ailelere yönelik uygulanan politikalar, daha spesifik olarak ise ailelerin çocuk yetiştirme maliyetlerine sağlanan nakdi yardımlar üzerine genel bir kavramsal çerçeve oluşturmak için kullanılmaktadır. Çelik aile politikalarını "ailenin bir kurum olarak korunması, güçlendirilmesi, temel fonksiyonlarını yerine getirebilmesi ve karşı karşıya kaldığı sorunların çözülmesi için ulusal ve uluslararası resmi kurum ve kuruluşlar tarafından ortaya konan her türlü yasal düzenlemeler, idari kararlar ve uygulamalar" (2007: 355) olarak tanımlamaktadır. Turğut ise aile politikaları için "doğrudan aileleri hedefleyen ve ailenin durumu ve işlevleri üzerinde etkide bulunma amacı taşıyan politikalar" (2016: 416) tanımını kullanmaktadır.

Zimmerman'a göre (1995: 3) ailelerin toplum içerisinde karşılaştıkları sorunların çözülmesi doğrultusunda birbirinden farklı, aynı anda da birbiriyle ilişkili nitelik taşıyan 
politikaların toplamı; aile politikalarını oluşturmaktadır: Boşanma, işsizlik, evsizlik, gelir eşitsizliği, aile içi şiddet, kürtaj, çocuk bakımı olanaklarının yetersizliği, cinsiyet veya 1rk temelli ayrımcılık, okullarda cinsellik eğitimi; söz konusu karşılaşılan sorunlar arasında yer almaktadır. Dumon (1991: 6-7), aile politikası uygulamalarını üç kategoride ele almaktadır. Bunlardan ilki, ailenin sürekli gelir sahibi olmasını, aynı anda istihdam sorununun da çözülmesini öngören güçlendirme politikalarıdır. İkinci kategoride, eğitim ve danışma gibi konularda ailenin desteklenmesine yönelik politikalar yer almaktadır. Üçüncü kategoride ise çocukların gündüz bakımı için kreşlerin yaygınlaştırılmasıyla aile bireylerinin yaptığı işlere destek niteliğinde uygulamalar öngörülmektedir. Kaufmann (2000: 421) ise aile politikalarının bir taraftan aile ve üyelerinin desteklenmesi çerçevesinde gerçekleştirilen sosyal yardım uygulamaları, öte yandan ise siyasal retorik ve hukuki söylem alanı olduğuna dikkat çekmektedir. Bu noktada, gerçekleştirilen aile politikaları uygulamalarının arka planında, devlet ve iktidar tarafından benimsenmiş olan ve yeniden üretilerek sürdürülen ideolojilerin karakteristiklerinin yattığını söylemek mümkündür. Başka bir deyişle, devletlerin bir kurumsal yapı olarak aileye bakış açıları, aileye yükledikleri ideolojik anlamlar, söz konusu uygulamaların kapsamının ve niteliğinin belirlenmesinde doğrudan etkili olmaktadır. Kaufmann (2000: 426-428), aile politikalarının oluşum sürecinde demografik, kurumsal, ekonomik, sosyo-politik faktörler dışında çocukların refahı ve toplumsal cinsiyet eşitliği faktörlerinin etkili olduğunu ifade etmektedir.

Demografik bir politika alanı olarak aile politikası, tarihsel süreçlerde nüfus yapısının kontrol ve denetiminin sağlanması açısından son derece önemli bir işleve sahip olmuştur. Özellikle II. Dünya Savaşı'ndan sonra sanayileşme ve kentleşme süreçlerinde yaşanan gelişmelerin sonucunda ailelerin geleneksel sosyal güvenlik işlevini önemli oranda kaybetmesiyle, devletlerin sosyal sistemlerinde yeni düzenlemeler yapma gerekliliği ortaya çıkmıştır. 20. yüzyılın son çeyreğinde yaşanan radikal ekonomik, sosyal, politik, demografik ve çevresel değişimler; aile refahının geliştirilmesine yönelik çabaların daha sistematik hâle getirilmesini zorunlu kılmıştır. Tüm bu etkenlerin bir sonucu olarak aile politikalarına ilişkin daha farklı yaklaşımlar ortaya çıkmış ve babalık yönelimli aile politikaları gibi yeni uygulamalar geliştirilmeye başlanmıştır.

\section{Aile Politikalarında Babalı̆̆ın Yeri}

Çocukların doğumu sonrasında, yetiştirilmesinde ve bakımında babaların yetersiz, süreksiz katılımının aile politikaları çerçevesinde çözülebilecek bir sorun olarak görülmeye başlanması; genelde ebeveynlik, özelde babalık konularında ortaya çıkan dönüşümlerin temel unsurunu oluşturmaktadır. Bir babanın çocuğuna bakması için belirli bir süre tatil hakkına sahip olması, sorumlu bir babalık modelinin oluşması için en etkili yöntemlerden biridir (Hobson ve Morgan, 
2002: 8). Bu bağlamda, erkeklerin çocuk bakımına daha fazla dikkatlerini çekmek ve katılımlarının teşvik edilmesi amacıyla yapılan yasal düzenlemeler, ebeveynlik ve mesleki sorumlulukların hem kadınlar hem de erkekler tarafından bir arada yürütülmesi olanaklarının genişletilmesinde önemli bir etkiye sahiptir ve ebeveynlik alanında toplumsal cinsiyet eşitliğinin oluşmasına katkı sağlamaktadır.

Kuzey Avrupa ülkelerinde, Avrupa Birliği (AB) düzenlemelerinden daha önce uygulanmaya başlandığı bilinen "ebeveynlik izni”; çocuk bakımı alanında sosyal hizmetlerin etkinleştirilmesi ve erkeğin de bakım için izin alabilmesini öngörmüştür. AB'nin eşitlik politikalarını tekdüzeleştirmesinin temel nedeni; genişlemenin bir sonucu olarak birlik üyesi ülkeler arasındaki farklılıkların artması doğrultusunda genel çerçevede sosyal politika, özelde ise toplumsal cinsiyet eşitliği alanındaki farklılıkların azaltılması hedefi ile benzer uygulamalara gidilmesi olarak görülmektedir. AB üyesi ülkelere bakıldığında, sadece yeni üyelerin değil, eski üyelerin aralarındaki farklılıklar da dikkat çekmektedir. Örneğin, Kuzey Avrupa ülkelerinde ebeveyn izninin kabulü 1970'li yılların ortalarına dayanırken AB çevresinde ise bu izin ancak 1996 yılında kabul edilmiş olan bir Konsey Yönergesi sayesinde müktesebat içine girmiştir; 1973 yılından beri birlik üyesi olan İngiltere' de ise bu düzenlemenin yasal zemine kavuşması 1999 yılını bulmuştur (Meryem, 2011: 23).

Avrupa Birliği'nde ebeveyn izinlerini düzenleyen ve 1996 y1lında kabul edilen yönerge çerçevesinde, çalışan ebeveynlerin çalışma hayatındaki yükümlülükleriyle ebeveynlik sorumluklarının bağdaştırılması amaçlanmıştır. Yönergede hem kadın hem de erkek çalışanlara, birlik üyesi devletler veya sosyal tarafların belirlediği şekilde, doğum veya evlat edinme nedeniyle çocuğun sekiz yaşına kadar olan süreçte asgari olarak dört ay ebeveyn izni hakkının tanınacağı belirtilmiştir (Ekin ve Kayırgan, 2014: 1056). Ebeveyn izniyle ilgili Avrupa Birliği düzeyinde kabul edilen standartlar, devletlerin izlediği politikaları birleştirmeyi amaçlamasına rağmen, yukarıda da ifade edildiği gibi, aile kurumunu desteklemeyi amaçlayan aile politikalarında ülkeden ülkeye değişiklik gösteren önemli farklılıklar mevcuttur. Babalık yönelimli aile politikaları için ebeveyn izni hakkının yasal olarak sağlanması çerçevesinde her ebeveynin izin kullanabilmesi, eşlerin ebeveyn iznini paylaşabilmesi, erkeklerin ebeveyn izni kullanması için özel koşulların sağlanmasının istenmemesi ve izinlerin ücretli olarak sağlanması gibi göstergeler önem arz etmektedir.

Toplumsal cinsiyet alanındaki eşitsizliğin azaltılması, toplumsal yaşamda kadının daha görünür hâle gelmesinin sağlanması, hem annenin hem de babanın ilgisinden tam fayda sağlayacak şekilde sağlıklı nesillerin yetişmesi hedefleri doğrultusunda; 2017 yılında Avrupa Komisyonu “İ̧s 
Yaşam Dengesi Yönergesi”ne yönelik bir öneri kabul edilmiştir. Yönergede babalık iznine "çalışan babalara bir çocuğun doğumundan hemen sonra verilen kısa süreli, ücretli izin" şeklinde yer verilmektedir. Bu babalık izinlerinin süresi Avrupa Birliği üyesi olan ülkelerde ortalama 9 gün iken Türkiye'de, 2016 yılında gerçekleştirilen düzenlemelerle, eşi doğum yaptığı takdirde memur babalar için 10 gün, işçi statüsünde çalışan babalar için ise 5 gün süreli ücretli izin şeklindedir. "İ̧ş Yaşam Dengesi Yönergesi”nde, tüm AB üyesi ülkelerde erkek çalışanlar için eşlerinin doğum yapması hâlinde; babalık izin haklarının ücretli olarak sağlanması, babalık ve ebeveyn izni olarak kullanılmak üzere asgari sürenin garanti edilmesi, ücretli babalık izin süresinin artırılması, ebeveyn izni çerçevesinde ödenen tazminatın artırılması ve izin alınacak zaman diliminin uzatılması sayesinde babaların hem babalık hem de ebeveynlik izninin teminat altına alınması önerilmektedir.

Bunlara ilaveten kadınlar ve erkekler arasında çalışma ve aile yaşamlarının daha iyi dengelenmesi, bakım sorumluluklarının daha iyi bir şekilde paylaşılmasının teşvik edilmesinin sağlanması doğrultusunda kapsamlı bir tamamlayıcı yasal ve politik tedbirler paketi ortaya konulmuş bulunmaktadır. Yasal önlemlerle, esnek çalışma düzenlemeleri ve özellikle aile ile ilgili izinler alanında mevcut AB yasal çerçevesinin modernleştirilmesi amaçlanmaktadır. Söz konusu yasal önlemler;

- Yeni doğan çocukları için -en az 10 iş günü süreli olmak üzere- babaların doğum izinlerinin ücretli şekilde sağlanması,

- 12 veya daha küçük yaşta çocuk sahibi olan ebeveynlerin izinlerinin 1 y1l içerisinde, 2 ay anneye ve 2 ay babaya olacak şekilde toplam 4 aylık periyotlar çerçevesinde güçlendirilmesi ve devlet tarafından bu ebeveynlik izinlerinin yüzde 80'inin ödenmesi şartının sağlanması,

- 12 veya daha küçük yaşta çocuk sahibi olan tüm çalışan anne ve babaların esnek çalışma düzenlemeleri (işyerinde esneklik, esnek çalışma saatleri ve çalışma saatlerinin azalması) talep etme hakkının genişletilmesi şeklinde ele alınmaktadır.

Politik tedbirler ise birlik üyesi devletleri desteklemek için bazı yasama dışı önlemleri kapsamaktadir. Bunlar;

- Ebeveynlerin ayrımcılığa ve işten çıkarılmaya karşı korunmasının sağlanması;

- Esnek çalışma düzenlemelerinde cinsiyet dengesinin gözetilmesinin teşvik edilmesi;

- Avrupa fonlarının uzun vadeli olarak, çocuk bakım hizmetlerinin iyileştirilmesi doğrultusunda daha etkili kullanılabilmesi şeklinde ele alınmaktadır (Kavas, 2018: 1-9).

Aile politikalarının toplumsal cinsiyet eşitliği odaklı hâle getirilmesi hedefiyle ve standart bir çerçeve oluşturmak amaciyla Avrupa Birliği düzeyinde gerçekleştirilen düzenlemelerin 
uygulanmasında, ülkeden ülkeye farklılıklar görülebilmektedir. Söz konusu ülkelerde geçerli olan refah rejimi modelinin toplumsal cinsiyet konusuna bakış açısı, aile politikası uygulamalarında ortaya çıkan farklılıkların temelinde yatan faktör olarak karşımıza çıkmaktadır. Dolayısıyla liberal, muhafazakâr ve sosyal demokrat refah rejimlerinin toplumsal cinsiyet bağlamında karşılaştırmalı olarak incelenmesi, konunun daha iyi anlaşılabilmesi açısından önemlidir.

\section{Farklı Refah Modellerinde Babalık Politikaları}

Aile politikası modelleri, sadece devletin aileye müdahalesinin biçimine göre değil, aynı anda genel olarak aileye ve özel olarak babalığa yönelik uygulanan desteklerin niteliğine göre de farklılık göstermektedir. $\mathrm{Bu}$ çalışmada; babalığın aile politikaları 1şığında incelenmesi doğrultusunda, Esping-Andersen'in üçlü refah devleti tipolojisi kullanılmaktadır. EspingAndersen'in toplumsal hakların kurumsallaştırılması ve ihtiyaçların piyasa dışında karşılanması gibi kriterlere göre yapmış olduğu sınıflandırmada kullandığı refah devleti modelleri; Anglosakson ya da liberal, Korporatist ya da muhafazakâr ve sosyal demokrat modellerdir (Koray, 2005: 198). Refah rejimlerinin işleyişi üzerine yapılan bu sınıflandırmanın temelinde; "devlet", "piyasa" ve “aile” kurumlarının işlevsel farklılığı yatmaktadır. Üçlü refah devleti tipolojisine göre; sosyal demokrat refah modelinde devletin, liberal modelde piyasanın, muhafazakâr modelde ise ailenin hâkim işlevi söz konusu olmaktadır (Ülgen ve Özalp, 2017: 638-639). Aşağıdaki tabloda, sınıflandırmada kullanılan modellerin temel özelliklerine karşılaştırmalı olarak yer verilmektedir.

Tablo 1: Esping-Andersen'in Refah Rejimi Modelleri

\begin{tabular}{|l|l|l|l|}
\hline Refah Rejimi & Liberal & Muhafazakar & Sosyal Demokrat \\
\hline Önde gelen ülkeler & ABD, İngiltere & Almanya & İsveç \\
\hline Felsefi temeli & Klasik liberalizm & $\begin{array}{l}\text { Muhafazakâr sosyal } \\
\text { politika }\end{array}$ & Sosyalizm / Marksizm \\
\hline $\begin{array}{l}\text { Piyasaya bağımlılık } \\
\text { oranı }\end{array}$ & Düşük & Orta & Yüksek \\
\hline Toplumsal haklar & Gereksinim temelli & Katkıya dayalı & Evrensel \\
\hline Refah önlemleri & Karma hizmetler & Transfer ödemeleri & Kamu hizmetleri \\
\hline Haklar & Düz oranlı ödenekler & Katkıya dayalı & Yeniden dağıtıcı \\
\hline $\begin{array}{l}\text { Sosyal politika } \\
\text { sağlayan kurumlar }\end{array}$ & Piyasa (kalıntısal) & Devlet (mesleksel) & Devlet (evrensel) \\
\hline
\end{tabular}

Kaynak: Ebbinghaus, B., Manow, P., 2001: 8-9; Van Voorhis, R.A., 2002: 5 akt. Özdemir, $2007: 132$. 


\section{Liberal Refah Modelinde Babalık}

Esping-Andersen'in yapmış olduğu refah devleti tasnifinin ilkini oluşturan "Liberal Refah Rejimleri”, farklı isimlerle de anılmaktadır. Başka bir ifade ile "Anglosakson Model” ya da "Kalıntı Refah Rejimleri” gibi terimler, liberal refah rejimleri ile aynı anlamda kullanılmaktadır. Literatürde liberal ya da kalıntı refah modeli olarak kabul gören bu model; devletin hâkimiyetinin sınırlı olduğu, piyasa merkezli bir modeli ifade etmektedir (Sarıca, 2008: 129-130). Buna göre; sosyal refah harcamaları sınırlı veya orta düzeyde gerçekleşmekte, işsizlik ve yaşlılık durumunda (İsviçre hariç) düşük veya orta seviyede gelir telafisi söz konusu olmaktadır. Ayrıca genç, yaşlı, hasta ve engelli vatandaşlara yönelik düşük düzeyde (İngiltere hariç) sosyal hizmet ve en düşük düzeyde gelir garantisi sağlanmaktadır (Marangoz, 2001: 105).

Liberal refah rejiminin geçerli olduğu ülkelerde, ailelere daha düşük düzeyde bir destek verildiği görülmekte; daha çok sorunlu ailelere yönelik -gelir durumlarına bağlı olarak- destek sağlanması söz konusu olmaktadır. Bunun yanında, özellikle çocuk bakımı alanında özel girişime inisiyatif tanınması, bu ülkeler için geçerli bir başka özellik olarak öne çıkmaktadır (Canatan, 2010: 36). İngiltere'de, 2008 yılından beri babalar; çocuk bakımı için iki haftalık ücretli izin hakkına sahiptir. Erkekler, çocuğun doğumundan sonraki ilk sekiz haftada ücretli ve ek olarak 13 hafta ücretsiz izin alabilmektedir. İzin hakkının kullanılabilmesi için kişinin; çocuğun biyolojik babası olması, son işyerinde en az 26 hafta çalışmış olması ve çocuğun bakımı için sorumluluk almaya hazır olması gibi koşulları yerine getirmesi gerekmektedir. Babaların ebeveyn izni kullanması üzerine yapılan araştırmalar, çoğu durumda erkeklerin çocuğun doğumundan sonra sadece bir haftalık ücretli izin aldığını göstermektedir. Bu durum genellikle, ikinci haftanın nasıl ücretlendirileceğine dair yeterli bilgi sahibi olunmamasından kaynaklanmaktadır; çünkü işverenler, ikinci hafta izin kullanmanın ekonomik açıdan kârlı olmaması için, ilk hafta daha fazla ücret ödemeyi tercih etmektedirler. Ancak bu haktan yararlanan babalar, aile politikasındaki değişiklikleri olumlu değerlendirmektedir ve böylesi asgari desteğin bile çocuklara daha fazla zaman ayırmalarına olanak sağladığı kanısındadırlar (Kaufmann vd., 2010: 323).

Liberal model çerçevesinde izlenen aile politikalarının diğer modellere göre daha az babalık yönelimli olduğu ve ebeveynlik alanında, erkeklerin paylaştı̆̆ı görevler ve toplumsal cinsiyet eşitliğinin oluşumu üzerinde önemli kısıtlamalar getirdiği görülmektedir. Söz konusu ebeveyn izni uygulamalarının gerçekleştirilmesindeki temel engelin işveren görüşüne verilen önem olduğu değerlendirilmektedir. $\mathrm{Bu}$ çerçevede; devlet tarafından uygulanan politikanın temelindeki ideoloji, babalara sağlanan destek ve bu desteği kullanabilmek için gerekli koşullar, erkeklerin ve kadınların normatif rolleri hakkında toplumsal cinsiyet görüşleri ve işverenlerin 
çalışan erkeklere yönelik davranışlarında aile sorumluluklarını göz önünde bulundurma durumları, aile politikalarının babalık yönelimli olmasını etkileyen temel faktörler arasında yer almaktadır.

\section{Muhafazakâr Refah Modelinde Babalık}

Esping-Andersen üçlü tasnifinde bu model için "Muhafazakâr Refah Modeli" terimini kullansa da model; "Korporatist Model”, "Kita Avrupası Modeli”, "Bismark Ülkeleri Modeli”, "Sosyal Sigorta Modeli” ve son dönemlerde daha çok kullanılan "Hristiyan Demokratik Rejimler" gibi çok farklı isimlerle adlandırılmaktadır. Almanya'nın en genel örnek olarak başı çektiği bu modelde; Belçika, Fransa, Avusturya ve kısmen İtalya bu sistemin özelliklerine sahiptirler (Özdemir, 2005: 245). İstihdam sürecine dâhil olmayan vatandaşlara yönelik sosyal güvenlik haklarının düzenlenmesinden dolayı model, "sosyal sigorta modeli” olarak da bilinmektedir. Piyasa ilişkileri dışlanarak refah hizmetlerinin devlet tarafından sağlanmaya çalışıldığı bu modelde, refah devleti hizmetlerinden yararlanmaya dair genel bir çerçeve bulunmamaktadır; şirketten şirkete, çalışandan çalışana bile farklılık görülebilmektedir (Aygül, 2010: 223-224). Yüksek düzeyde sosyal tabakalaşma, orta düzeyde dekomüdifikasyon (piyasaya bağımlılık), desantralizasyon (yerelleşme) bu refah modelinin diğer özellikleri olarak öne çıkmaktadır.

Muhafazakâr refah modeli kapsamında uygulanan aile politikasıpratiklerinde, kamusal ve özel alanda toplumsal cinsiyete dayalı iş bölümü göz önünde bulundurularak ebeveynlerin istihdam şekilleri dikkate alınmakta ve ailelere ortalama düzeyde destek verilmektedir. Almanya'nın aile politikasında; 2000'li yılların ortalarında, doğum oranlarında büyük bir düşüş gözlenmesinden dolayı önemli değişiklikler yapılmıştır. Çocuklu kadınların mesleki istihdamının artırılması ve ebeveynlik konusu toplumsal cinsiyet asimetrilerinin düzeltilmesine yönelik olarak düzenlenmiştir (Rürup, Gruescu, 2003; Henninger vd., 2008: 293). Almanya'da, 2007 yılında kabul edilen yeni gelir düzenleme tasarısına göre ebeveyn izni süresi, 12 ay olarak düzenlenmiştir. Alman aile politikasında bir değişimi yansıtmakta olan bu düzenleme, çalışan annelerin çocuk bakımı sürecinde yeni bir gelir düzenlemesine ihtiyacı olduğunu kabul etmektedir. Babalara ise ebeveyn izni olarak ek iki ay izin ücreti ödenmekte, 14 haftalık ebeveyn izin hakkı sunulmaktadır. Çocuk bakımı desteği ise ebeveynin gelirine göre hesaplanmakta, izne ayrılan ebeveynin aylık maaşının 2/3'ü olarak ücretlendirilmektedir (Plantenga, 2008; Parlak, 2016: 76).

Yapılan düzenlemelerle ebeveynlik izni hakkından yararlanan erkeklerin oranının \%5'ten \%27'ye yükseltilmesi hedeflenmiş olmasına rağmen, 2007 yılında babaların sadece \%10,5’i bu haktan yararlanmıștır. Bu kișilerin yarısından fazlası, ilk 2 ay içerisinde destekten faydalanmıştır (Henninger vd., 2008: 300). Öte yandan erkeklerin sosyo-ekonomik durumu ne kadar yüksek olursa, ebeveyn iznini kullanma oranının da o kadar düşük olduğu 
görülmüştür. Bu durum yalnızca ekonomik nedenlerle değil, aynı zamanda erkeklerin toplumsal cinsiyet tutumları ve işverenlerin bu konudaki tavırlarının her zaman olumlu olmadığıyla ilişkilendirilmektedir. Muhafazakâr refah modeline göre aile politikaları uygulamalarında, babalara tanınan iki aylık izin hakkının ebeveynlik alanındaki iş bölümü üzerinde önemli bir dönüşümü sağlayamadığı, çocuk bakımının hâlâ annenin sorumluluğu olarak algılandığ1 ve sonuç olarak geleneksel babalık modelinin hem erkekler hem de emek piyasası tarafindan desteklendiği görülmektedir.

\section{Sosyal Demokrat Refah Modelinde Babalık}

Sosyal demokrat refah devleti rejimleri, "Evrensel Refah Rejimleri”, "İskandinav Model” gibi farklı terimlerle de ifade edilmektedir. $\mathrm{Bu}$ refah modelinin özelliklerini taşıyan ülkeler; Norveç, Danimarka, Hollanda, Finlandiya olmakla birlikte en önde gelen model ülke İsveç’tir ve bazı sosyal bilimciler bu modeli “İsveç Modeli” olarak da adlandırmaktadır. Evrensel bir yapıya sahip olması, bu rejimin öne çıkan özelliğidir. Bununla birlikte sosyal dayanışma ve sınıflar arası eşitlik, bu modeli diğer refah modellerinden ayırmaktadır (Özdemir, 2005: 248). Bu model çerçevesinde uygulanan refah ve istihdam politikalarında, vatandaşların üretken potansiyelinin en üst seviyeye çıkarılması doğrultusunda, "verimlilik" odaklı bir yaklaşım benimsenmektedir. Yüzeysel olarak bakıldığında bu yaklaşım, Amerika Birleşik Devletleri'nde (ABD) uygulanmakta olan çalışma temelli devlet (workfare) anlayışı ile benzerlik göstermektedir. Fakat ABD'de söz konusu olan "çalışma temelli anlayış", sosyal yardımların işin kabul edilmesi durumunda geçerli olduğunu öngörmekte iken; İskandinavya ülkelerindeki "verimlilik" yaklaşımı ise tüm vatandaşların çalışması için gerekli kaynaklara ve motivasyona sahip olmasının refah devleti tarafından teminat altına alınması gerektiğini (ve çalışılacak işlerin de mevcut olduğunu) ifade etmektedir (Esping-Andersen, 2003: 80). Kadınların emek piyasasına katılımının ve genel olarak toplam istihdamın yüksek oranda gerçekleşmesi, işsizlik ve yaşlılık alanlarında yürütülen sosyal politika faaliyetleri, toplumun tüm kesimlerini kapsayacak şekilde uygulanan sosyal hizmetler ve gelir eşitsizliğinin düşük düzeyde olması; bu modelin ayırt edici özellikleri olarak öne çıkmaktadır (Marangoz, 2011: 101). Toplumsal cinsiyet eşitliği odaklı mekanizmaların hem kamusal hem de özel alanda geliştirilip uygulanmasının hedeflenmesi sosyal demokrat refah modelinin özgünlüğünü ortaya koymaktadır.

Sosyal demokrat refah modeli; hem iş hem de ebeveynlik konusunda toplumsal cinsiyet eşitliğinin sağlanmasına yönelik tüm ailelere sağlanan devlet destekleri ve çalışan ebeveynlere sağlanan yüksek düzeyde maddi destekler ile karakterize edilmektedir. İsveç, 1974 y1lında annelik iznini “ebeveyn izni” olarak değiştirerek dünyada çocuk bakımı için erkeğin de izin alabilmesini 
sağlayan ilk ülke olmuştur (Kaplan, 2010: 24). 1995 y1lında Norveç'te, 1997 yılında ise İsveç’te; bir aile politikası uygulaması olarak erkeklere, eşlerine devredilemeyecek şekilde çocuk bakımı için iki aylık ücretli babalık izni hakkı tanınmıştır (Haas ve Hwang, 2009: 304). 2001 yılından itibaren ise her iki ebeveyne de çocuk bakımı için ebeveynler arasında eşit olarak paylaştırılmış, bir ebeveynden diğerine aktarılamayan 60'ar gün ve ayrıca kendi aralarında aktarılabilecek şekilde 360 gün izin kullanma hakkı tanınmıştır. Söz konusu izin haklarının elde edilmesi için ebeveynlerin çocuğun doğumundan önce, en az 240 gün çalışmış olması şartı mevcuttur. Ayrıca, ebeveynlerin yarı zamanlı veya tam zamanlı çalışmalarına uygun bir şekilde, çocuk sekiz yaşına gelene kadar ebeveyn izninin parçalı şekilde kullanılabilmesi olanağı sağlanmıştır. İzinlerin ücretlendirilmesi ise 16 aylık iznin 13 ayında ebeveynin gelirinin \%80'inin, geriye kalan 3 ayda ise günlük 180 İsveç kronu ödenecek şekilde düzenlenmiştir (Duvander, Ferrarini ve Thalberg, 2005: 10). 2013 y1lında gerçekleştirilen yasal düzenlemeler sayesinde, Norveç’te babalar; çocuklarının doğumundan itibaren 14 hafta ücretli izin yapma hakkında sahiptirler. Yasal olarak kullanmak zorunda oldukları bu izinlerin tam kullanılmaması hâlinde, devlet çocuk yardımı azaltılmaktadır (Kavas, 2018: 2).

Sosyal demokrat refah modeli çerçevesinde uygulanan ve toplumsal cinsiyet eşitliği temelinde oluşturulmuş olan aile politikası pratiklerinde; çocuk bakımı için gerekli maddi desteğin sağlanması, ebeveyn izni kullanmak için kurumsallaşmış esnek imkânların mevcutluğu, babalık yönelimli politikaların izlenmesi, erkeklerin çocuk bakımına aktif bir şekilde katılmalarının ve kendilerine tanınan babalık izni haklarını kullanmalarının teşviki söz konusudur.

Esping-Andersen'in üçlü refah rejimi sınıflandırması; rejim türleri arasındaki karmaşıklığı önemli görmediği ve gereğinden çok basitleştirdiğinden, ailenin ve diğer enformel ilişkilerin refah sunumunda oldukça etkili rol oynadığı Güney Avrupa devletlerini sınıflandırmaya dahil etmediğinden dolayı, Leibfried başta olmak üzere bazı araştırmacılarca eleştirilmiştir (Özdemir, 2005: 255). Bu eleştiriler çerçevesinde Leibfried; aile bağları diğer devletlere göre daha kuvvetli olan Akdeniz devletlerini (İtalya, Portekiz ve İspanya), Güney Avrupa refah devletleri olarak sınıflandırmıştır (Leibfried, 1993; Özdemir, 2005: 258). Söz konusu ülkelerde, devlet tarafindan herkes için asgari bir gelir güvencesi sağlanması amaçlanmamaktadır. Aile hizmetleri ve kurumlarının özel sektör ve devlet arasında paylaşıldığı bu ülkelerde, açık ve düzenli bir aile politikasından bahsetmenin pek mümkün olmadığı görülmektedir. Türkiye de aile politikaları açısından, daha çok Güney Avrupa refah devletleri sınıflandırmasında değerlendirilmektedir (Canatan, 2010: 36-37). 


\section{Babalık Yönelimli Aile Politikalarının Uygulanmasındaki Sorunlar}

Avrupa ülkelerinde sorumlu baba rolünün teşvik edilmesi çerçevesinde yapılan çalışmalar; ebeveynlere izin hakkı tanınmasına yönelik mevzuatların standartlaştırılması çabalarına rağmen ebeveyn izni hakkını kullanan erkeklerin sayısının yeterli seviyede olmadığını göstermektedir (Klinth, 2008: 21). Sosyal demokrat modelin uygulandığı İskandinavya ülkelerinde, aile politikaları çerçevesinde sunulan olanakların babalar tarafından kullanılması hem kamusal alanda hem de ebeveynlik alanında amaçlanan toplumsal cinsiyet hedeflerine ulaşılması noktasında öne çıkmaktadır. Fakat bu ülkelerde de ebeveyn rollerinin uygulanmasında, belirli bir toplumsal cinsiyet asimetrisi varlığını sürdürmektedir. $\mathrm{Bu}$ durum; erkeklerin çoğunun ebeveyn iznini kullanmaları, fakat bu izin süresinin kısa olması ile gerekçelendirilmektedir. Örneğin 2007 yılında, İsveç'te babaların \%90'ının kendilerine ait olan izinleri kullandıkları görülmüştür; ancak geriye kalan paylaşılabilir izinlerin \%79'u anneler tarafından kullanılmıştır (Haas ve Hwang, 2009: 304). Buna rağmen bu göstergelerin diğer Avrupa ülkelerine göre daha süreklilik gösteren nitelikte olduğu açıkça görülmektedir. Örneğin, Fransa'da 1999 yılında babaların sadece \%1'i bu olanaktan yararlanmış ve 2003 yılında bu oran \%2'ye kadar yükselmiştir (Almqvist, 2008: 194). Almanya'da, 2007'de yeni aile politikası uygulamalarının yürürlüğe girmesinden sonra, ebeveynlik izni hakkını kullanan erkeklerin oranı \%10,5'e yükselirken yararlananların yarısından fazlası sadece iki ay izin kullanmış ve bu hakkı kullananların sadece \%1,9'u (annelerde bu oran \%78,1 iken) 12 aylık ebeveyn izninden yararlanmıştır (Henninger vd., 2008: 300).

Babalığa ilişkin yasal ve söylemsel düzenlemeler arasında hâlâ ciddi bir uçurumun olduğu görülmektedir. Bu noktada, babalık izni hakkından yararlanan erkeklerin sayısının yetersiz olması ve babaların çocuk bakımı için ayırdıkları zamanın annelerden çok daha az olması önemli sorun alanlarını oluşturmaktadır (Hobson, 2002: 11). İşverenlerin tutumları ve toplumsal olarak değişiklik gösteren hegemonik erkeklik algısı, babalık yönelimli aile politikalarının uygulanmasını zorlaştıran temel etkenler olarak dikkat çekmektedir. İşveren ve çalışanlara sağlanan kurumsal destek; yasalar çerçevesinde belirlenmiş kurallar ve bireysel babalık uygulamaları arasında bir aracı rolü oynamaktadır. İşverenin ve iş arkadaşlarının tutumları, erkeklerin kendilerine tanınan babalık izni hakkından yararlanmasında ve izin süresinin belirlenmesinde doğrudan etkili olmaktadır. İsveç'te kurumsal destek üzerine yapılan araştırmalar; çok sayıda kadın çalışanın bulunduğu büyük kamu şirketlerinde, erkeklerin daha çok ebeveyn izni kullandığını göstermektedir, çünkü bu işletmelerde işverenin (bu durumda devletin) ve iş arkadaşlarının babalık yönelimli tutumları söz konusudur. Çalışanlar arasında keskin bir iş bölümü ve sorumluluk paylaşımı yapılmış olan küçük ve özel şirketlerde ise erkeklerin babalık izni kullanmaları, diğer çalışanlar tarafından önemsenmemektedir. Ayrıca çocuk bakımı için babaların izin kullanması 
konusu, aynı zamanda sınıfsal bir boyuta da sahiptir. Çocuk bakımı için işçi sınıfının temsilcileri, orta sınıf temsilcilerinden (orta ve üst düzey yöneticiler) çok daha az izin kullanmaktadırlar, çünkü bu konuda iş arkadaşlarından nadiren destek almaktadırlar (Haas ve Hwang, 2009: 306). Dolayısıyla bir işletmenin büyüklüğü, mülkiyet biçimi, çalışanların toplumsal cinsiyet dağılımı, çalışan erkeğin ait olduğu sınıf gibi özellikler; babalık yönelimli aile politikalarının uygulanmasında kimi zaman olumlu, kimi zaman ise olumsuz etkilere sahip olabilecek temel faktörler olarak öne çıkmaktadır.

Toplumsal cinsiyet ideolojisi ve ait olunan toplumun hegemonik erkeklik alg1sı, aynı zamanda aile politikasını ve babalık modellerini de etkilemektedir. Toplumsal cinsiyete dayalı iş bölümü ve kamusal alanda erkek egemenliğine dayanan hegemonik erkeklik kavramsallaştırması, geleneksel veya "hiç olmayan" bir babalık modelini içermektedir (Tereðkinas, 2005: 17). Hegemonik erkekliğin tarihsel süreçte geçirdiği dönüşümler sonucunda babalık, erkekliğin "hayata geçirilmesinde" uzak bir kavram olmaktan çıkmaya; erkeklerin sadece maddi olarak değil, aynı anda zamansal ve duygusal katılımının da söz konusu olduğu bir kavram hâline gelmeye başlamıştır. İsveç’te ve Fransa'da erkeklerin ebeveynlik izni kullanmalarının nedenleri üzerine yapılan karşılaştırmalı bir çalışma, izin kullanma kararını verme sürecindeki belirleyici güdülerden birinin (emek piyasasında konum ve gelir düzeyi ile birlikte) erkekliğe dair normatif algı olduğunu belirlemiştir. Fransızlar hem toplumsal cinsiyet ideolojisi hem de gündelik hayat bağlamında, klasik hegemonik erkeklik temsili sergilemektedir ve bu doğrultuda İsveçlilerle karşılaştırıldığında, ebeveynlik izni hakkını daha az kullanmaktadırlar. Toplumsal cinsiyet eşitliği hedefi çerçevesinde yürütülen aile politikaları ile karakterize edilen İsveç’te, hegemonik erkeklik kavramı sorumlu babalığı dışlamamakta; aksine onu normatif erkekliğin temel bir unsuru olarak görmektedir (Almqvist, 2008: 194). Dolayısıyla toplumdaki normatif erkekliği ve kadınlığı belirleyen toplumsal cinsiyet ideolojisi; sadece aile politikasının oluşturulmasında değil, aynı zamanda erkekler tarafından babalık izninin kullanılmasına karar verme sürecinde de önemli bir rol oynamaktadır.

\section{Sonuç}

Toplumdan topluma farklılık gösteren ebeveynlik tanımlamaları temelinde şekillenen aile politikaları, babalık kurumunun ve babalık pratiklerinin sınırlarını belirleyen kurumsal çerçeveleri oluşturmaktadır. Babalığa ilişkin farklı şekillerde normatif tanımlamaların, aynı anda yasal norm ve uygulama esaslarının düzenlenmesini sağlayan bu politikalar; bağlamsal bir niteliğe sahiptir. Hukuki bağlamda babanın statüsü; onun çocuğun babası olmasını belirleyen kıstaslarla, çocuğun annesiyle beraberken veya ayrılma durumunda çocuğa karşı hak ve yükümlülüklerinin neler 
olduğuyla belirlenmektedir. İdeolojik bağlamda ise aile politikası uygulamaları çerçevesinde hedeflenen normatif babalık modeli oluşturulmaktadır. Çalışan erkeklere toplumsal cinsiyet açısından nötr statüye sahip bir vatandaş olmak yerine, aile sorumlulukları olan bir çalışan erkek olmak için gerekli kurumsal ve söylemsel olanaklar sunulmaktadır.

Çalışma kapsamında; farklı refah rejimleri bağlamında aile politikalarındaki babalık yönelimli uygulamaların karşılaştırmalı incelemesi sonucunda, aile politikalarının toplumsal cinsiyet ideolojisinin yeniden üretildiği ve sürdürüldügü alanlardan biri olduğu görülmektedir. Hem çalışma hem de aile alanında toplumsal cinsiyet eşitliğine odaklanan aile politikası söz konusu olduğunda, devlet tarafından babalık yönelimli bir politika izlenerek erkekler için yeni ve sorumlu bir babalık modeli doğrultusunda gerekli koşullar oluşturulmaktadır. Erkeklerin ev geçindirme rolüyle özdeşleştiği, geleneksel ailenin söz konusu olduğu ülkelerde ise aile politikası uygulamalarının erkeklerin ebeveynlik statülerini etkili bir şekilde sürdürmelerini daha düşük seviyede desteklediği görülmektedir.

Toplumsal cinsiyet düzeninin egemen ideoloji tarafından istenildiği şekilde oluşturulması ve meşrulaştırılması sürecinde aile politikaları, stratejik bir öneme sahiptir. Devletler tarafından benimsenmiş ve uygulanmakta olan toplumsal cinsiyet ideolojisine dayalı aile politikaları, ebeveynlik alanının da toplumsal cinsiyete göre düzenlenmesini sağlamaktadır. Sosyal demokrat refah modeli çerçevesinde uygulanan aile politikaları, erkeklerin çocuk bakımına aktif bir şekilde katılmalarını doğrudan teşvik etmekte iken muhafazakâr ve liberal refah modellerinde çocuk bakımının annelikle özdeşleştirilmesi sürdürülmektedir. Dolayısıyla, söz konusu modellerin uygulandığı ülkelerde geçerli olan aile politikalarıyla; ebeveynlik uygulamalarına ilişkin toplumsal cinsiyete dayalı normatif annelik ve babalık standartlarının yeniden üretilerek sürdürüldüğü görülmektedir.

\section{Summary}

Impacts of global, social, cultural and economic changes on institutional structure of the family are rapidly increasing. As a result of this interaction, it is inevitable that families face various problems to raise their children in healthy way, about childcare and child development. These changes transform not only the family that is accepted as a small social group but also the society as a whole. These transformations increases attention on family and marriage topics and these increases reveal the necessity for the state to handle this topic from more holistic and dynamic perspective. At this point, it is observed that state develops certain policies to ensure continuity of family. 
Family policies that are shaped around different parenting definitions among societies create institutional framework that determines limits of fatherhood and father practices. These policies that organises legal norms and applications of different normative definitions of fatherhood simultaneously have contextual characteristic. In legal context, status of father defines criteria that determines him as the father and rights and liabilities to the child when he is together with or separated from child's mother. In ideological context, targeted normative fatherhood model is formed under family policy practices. Working men should have necessary institutional and discursive opportunities to be a working men with family responsibilities instead of facing a neutral gender status in the society.

In this study, within Esping-Andersen's three worlds of welfare classification, fatherhoodoriented practices in family policies are investigated under parenthood and which gender ideology has shaped these practices is investigated. In this sense, after defining a general framework about family policy and fatherhood in family policies, fatherhood-oriented practices in liberal, conservative and social democratic welfare regimes are comparatively analysed; in the last section of this study, problems with fatherhood-oriented family policies are discussed.

At European Union level, practices to define standardised framework can differ between countries to transform family policies in gender focused form. Perspective of welfare regime model in these countries to gender is the main factor for differences in family policy practices. In family policy practices created based on gender equality and applied under social democratic welfare model framework, necessary monetary support for childcare, institutionalised flexibility for parental leave, following fatherhood-oriented policies, active participation of men in childcare and fatherhood leaves should be encouraged. According to conservative welfare model, in family policy practices, it can be seen that two-month parental leave for fathers fail to generate important transformation on division of labour, childcare is perceived as mother's responsibility and as a result, traditional fatherhood model is supported by both men and labour market. According to family policies under liberal model framework, it can be seen that this model has less fatherhoodoriented structure and this model presents important restrictions on tasks shared by men in parenthood and gender equality.

As a result of comparative analysis of fatherhood-oriented practices in family policies in different welfare regimes, it can be seen that family policies are one of the fields that re-create and sustain gender ideology. When family policies that focuses on gender equality in both work and family field, state follows a fatherhood-oriented policy and create necessary conditions for new and responsible fatherhood. In countries with traditional family where males are associated with 
earning money, it can be seen that family policy practices support sustaining parenthood status of men at lower levels.

Family policies have strategic importance to create and legitimise gender order by dominant ideology. Family policies adopted and applied by state which are based on gender ideology enable parenthood field to be organised for gender. While family policies applied under social democratic welfare model directly encourage male active participation in childcare, conservative and liberal welfare models continue to associate childcare with motherhood. Therefore, family policies in countries where these models are applied, it is seen that gender-based normative motherhood and fatherhood standards in parenthood practices are reproduced and sustained.

\section{Kaynakça}

Almqvist, A. L. (2008). Why Most Swedish Fathers and Few French Fathers Use Paid Parental Leave: An Exploratory Qualitative Study of Parents. Fathering: A Journal of Theory, Research \& Practice about Men as Fathers, 6 (2), 192-200.

Aygül, C. (2010). Neo-Liberal Dönüşüm Sonras1 Refah Devleti Kuramları. Memleket Siyaset Yönetim Dergisi, 5 (14), 210-247.

Canatan, K. (2010). Aile Politikaları ve Türkiye Örneği, Umran Dergisi, 187, 34-39.

Çelik, A. N. (2007). Aile Politikaları ve Yasal Sorunlar. Ö. Çaha (Ed.). Günümüzde Aile, (355364). İstanbul: Ensar Neşriyat.

Daly, M., Clavero, S. (2002). Contemporary Family Policy: A Comparative Review of Ireland, France, Sweden and the UK. Dublin: Institute of Public Administration.

Dumon, W. (1991). Avrupa Topluluğu Ülkelerinde Aile Politikaları. Aile ve Toplum Dergisi, 1 (2), $5-15$.

Duncan, S. (2000). Introduction: Theorizing Comparative Gender Inequality. B. Pfau-Effinger, S. Duncan (Ed.). Gender, Economy and Culture in the European Union, (1-23). UK: Routledge.

Duvander, A. Z., Ferrarini, T., Thalberg, S. (2005). Swedish Parental Leave and Gender Equality: Achievements and Reform Challenges in a European Perspective. Stockholm: Institute for Futures Studies.

Ebbinghaus, B., Manow, P. (2001). Introduction: Studying Varieties of Welfare Capitalism. B. Ebbinghaus, P. Manow (Ed.). Comparing Welfare Capitalism: Social Policy and Political Economy in Europe, Japan and the USA, (1-24). London: Routledge. 
Ekin, A., Kayırgan, H. (2014). Uluslararası Alanda ve Türk Hukukunda Eşit Davranma İlkesi Bağlamında Ebeveyn İzni. Dokuz Eylül Üniversitesi Hukuk Fakültesi Dergisi, 15, 1045-1066.

Esping-Andersen, G. (1990). The Three Worlds of Welfare Capitalism. New Jersey: Princeton University Press.

Esping-Andersen, G. (2003).Social Foundations of Postindustrial Economies. New York: Oxford University Press.

Haas, L., Hwang, C. P. (2009). Is Fatherhood Becoming More Visible at Work? Trends in Corporate Support for Fathers Taking Parental Leave in Sweden. Fathering: A Journal of Theory, Research, \& Practice about Men as Fathers, 7 (3), 303-321.

Henninger, A., Wimbauer, C., Dombrowski, R. (2008). Demography as a Push toward Gender Equality? Current Reforms of German Family Policy. Social Politics: International Studies in Gender, State and Society, 5 (3), 287-314.

Hobson, B., Morgan, D. (2002). Introduction: Making Men into Fathers. B. Hobson (Ed.) Making Man into Fathers: Men, Masculinities and the Social Politics of Fatherhood, (1-22). UK: Cambridge University Press.

Hobson, B. (1994). Solo Mothers, Social Policy Regimes and the Logics of Gender. D. Sainsbury (Ed.). Gendering Welfare States, (170-188). UK: SAGE Publications.

Kaplan, S. Z. (2010). Bizde Doğum İzni, İsveç'te Ebeveyn İzni. Petrol-İş Kadın Dergisi, 37, 2425.

Kaufmann, F. X. (2000). Politics and Policies Towards the Family in Europe: A Framework and an Inquiry into Their Differences and Convergences. F. X. Kaufmann, A. Kuijsten, H. J. Schulze, K. P. Strohmeier (Ed.). Family Life and Family Policies in Europe: Problems and Issues in Comparative Perspective, 419-490. Oxford : Oxford University Press.

Kaufmann, G. , Lyonette, C., Crompton, R.. (2010). Post-Birth Employment Leave Among Fathers in Britain and the United States. Fathering: A Journal of Theory, Research, \& Practice about Men as Fathers, 8 (3), 321-340.

Kavas, A. (2018). Türkiye'de Babalar Çocuk Bakamıyor, Türkiye Ekonomi Politikaları Araştırma Vakfi, Değerlendirme Notu, N. 201828, Temmuz https://tepav.org.tr/upload/files/15330375176.Turkiye_de_Babalar_Cocuk_Bakamiyor.pdf, Erişim Tarihi: 25.03.2019. 
Klinth, R. (2008). The Best of Both Worlds? Fatherhood and Gender Equality in Swedish Paternity Leave Campaigns, 1976-2006. Fathering: A Journal of Theory, Research, \& Practice about Men as Fathers, 6 (1), 20-38.

Koray, M. (2011). Avrupa Birliği ve Türkiye'de "Cinsiyet” Eşitliği Politikaları: Sol-Feminist Bir Eleştiri. Çalışma ve Toplum Dergisi, 2, 13-54.

Koray, M. (2005). Avrupa Toplum Modeli. Ankara: İmge Kitabevi.

Leibfried, S. (1993). Towards a European Welfare State. C. Jones (Ed.). New Perspectives on the Welfare State in Europe, (133-156). London: Routledge Press.

Lewis, J. (1992). Gender and the Development of Welfare Regimes. Journal of European Social Policy, 2 (3), 159-173.

Marangoz, Ş. (2001). Refah Devleti: Gelişimi, Oluşumu, Modelleri ve Güncel Değişimler. İstanbul Üniversitesi Sosyal Bilimler Enstitüsü, Yüksek Lisans Tezi, İstanbul.

Özdemir, S. (2007). Küreselleşme Sürecinde Refah Devleti. İstanbul: İTO Yayınları.

Özdemir, S. (2005). Sosyal Gelişim Düzeyleri Farklı Refah Devletlerinin Sınıflandırması Üzerine Bir İnceleme. Sosyal Siyaset Konferanslart, 49, 231-266.

Parlak, K. N. (2016). Avrupa Birliği’nde İş-Yaşam Dengesine Yönelik Uyumlaştırma Politikaları: Ebeveyn İzni. Bilgi Dergisi, 32, 56-91.

Park, M, Jeong-Won, H., In-Ja S. (2002). Gender and the Welfare State: The British Feminist Critiques. Journal of Korean Home Economics Association, 3 (1), 73-94.

Plantenga, J., Remery C., Jill R. (2008), Gender Mainstreaming of Employment Policies A Comparative Review of Thirty European Countries, Belgium: European Commission.

Rürup, B., Gruescu, S. (2003). Nachhaltige Familienpolitik im Interesse einer aktiven Bevölkerungsentwicklung. Gutachten im Auftrag des Bundesministeriums für Familie, Senioren, Frauen und Jugend.https://www.bmfsfj.de/blob/93398/99ab881b95ba1 3503e19c5baa924a839/broschuere-nachhaltige-familienpolitik-ruerup-data.pdf Erişim Tarihi 17.04.2019.

Tereðkinas, A. (2005). Men on Paternity Leave in Lithuania: Between Hegemonic and Hybrid Masculinities. A. Tereðkinas, J. Reingardienè (Ed.). Men and Fatherhood: New Forms of Masculinity in Europe, (11-37). Vilnius: Egrimas.

Turğut, F. (2016). Türk Siyasetinde Son Dönem Aile Politikaları. Selçuk Üniversitesi Edebiyat Fakültesi Dergisi, 35, 411-426. 
Ülgen, G. ve Özalp, L. F. A.. (2017). Refah Rejimleri Sınıflandırma Çalışmaları: Cinsiyet Boyutları. Marmara Üniversitesi İktisadi ve İdari Bilimler Dergisi, 39 (2), 637-656.

Van Voorhis, R. A. (2002). Different Types of Welfare States? A Methodological Deconstruction of Comparative Research.Journal of Sociology and Social Welfare, 29 (4), 3-18.

Zimmerman, S. (1995). Understanding Family Policy: Theories and Applications. California: Sage Publications. 